
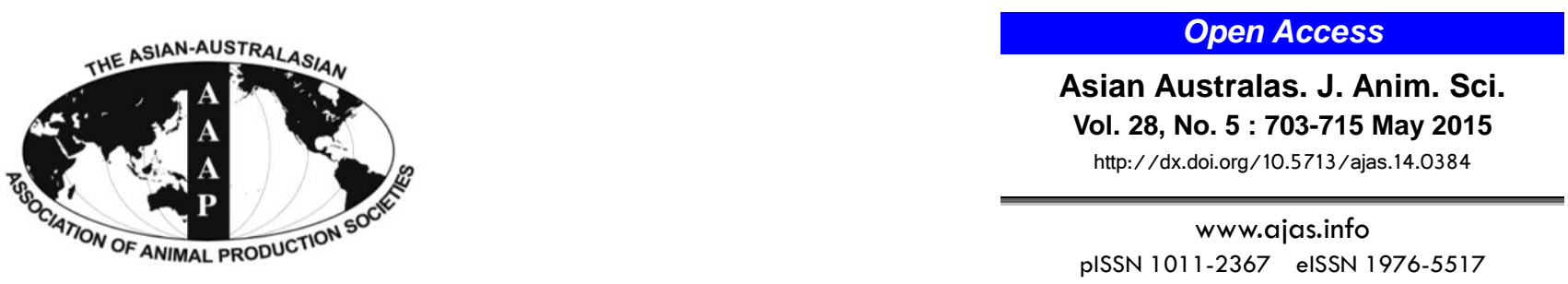

\title{
Modelling Pasture-based Automatic Milking System Herds: Grazeable Forage Options
}

\author{
M. R. Islam*, S. C. Garcia, C. E. F. Clark, and K. L. Kerrisk \\ Dairy Science Group, Faculty of Veterinary Science, The University of Sydney, Camden, NSW 2570, Australia
}

\begin{abstract}
One of the challenges to increase milk production in a large pasture-based herd with an automatic milking system (AMS) is to grow forages within a $1-\mathrm{km}$ radius, as increases in walking distance increases milking interval and reduces yield. The main objective of this study was to explore sustainable forage option technologies that can supply high amount of grazeable forages for AMS herds using the Agricultural Production Systems Simulator (APSIM) model. Three different basic simulation scenarios (with irrigation) were carried out using forage crops (namely maize, soybean and sorghum) for the spring-summer period. Subsequent crops in the three scenarios were forage rape over-sown with ryegrass. Each individual simulation was run using actual climatic records for the period from 1900 to 2010. Simulated highest forage yields in maize, soybean and sorghum- (each followed by forage rape-ryegrass) based rotations were 28.2, 22.9, and $19.3 \mathrm{t}$ dry matter/ha, respectively. The simulations suggested that the irrigation requirement could increase by up to $18 \%, 16 \%$, and $17 \%$ respectively in those rotations in El-Niño years compared to neutral years. On the other hand, irrigation requirement could increase by up to $25 \%, 23 \%$, and $32 \%$ in maize, soybean and sorghum based rotations in El-Nino years compared to La-Nina years. However, irrigation requirement could decrease by up to $8 \%, 7 \%$, and $13 \%$ in maize, soybean and sorghum based rotations in La-Nina years compared to neutral years. The major implication of this study is that APSIM models have potentials in devising preferred forage options to maximise grazeable forage yield which may create the opportunity to grow more forage in small areas around the AMS which in turn will minimise walking distance and milking interval and thus increase milk production. Our analyses also suggest that simulation analysis may provide decision support during climatic uncertainty. (Key Words: Automatic Milking System, Agricultural Production Systems Simulator, Dairy, Forage Options, Forage Rotations)
\end{abstract}

\section{INTRODUCTION}

Previous research conducted at Camden, NSW, Australia over two years showed that the software modelling framework, Agricultural Production Systems Simulator (APSIM) can be used effectively to simulate and validate yield and nutrient-use efficiencies of an annual cycle of a triple-crop complementary forage rotation (CFR) of maize (grown for silage), forage rape and field peas (Islam and Garcia, 2010). Many researchers (Carberry et al., 1996; Chauhan, 2010) also reported that modelling approaches can assist in arriving at initial estimates of various productive parameters of crops or crops in rotations

* Corresponding Author: M. R. Islam. Tel: +61-2-9036-7750, Fax: +61-2-4655-2374, E-mail: md.islam@sydney.edu.au Submitted May 21, 2014; Revised Aug. 31, 2014; Accepted Sept. 9, 2014 based on historic climate data and soil characteristics without having to conduct expensive field experiments. These evidences indicate that new research questions can be tested using APSIM or that various treatment options can be screened to prioritize treatments for field experiments. Thus there is a good prospect of APSIM to be used as a tool to screen forage options that can supply grazeable forages for a large herd (400 to 800 cows) throughout the year in an automatic milking system (AMS) dairy.

Pasture-based AMS systems generally have larger herds which pose unique challenges to AMS (Jago et al., 2007) compared to herds housed indoors. Jago et al. (2004) and Jago and Kerrisk (2011) reported that the long walking distances associated with pasture-based large herds milked with AMS reduces cow trafficking and milking frequency. The potential exists to minimize average walking distances if the volume of grazeable forages grown in close vicinity to 
the dairy is increased. Incorporation of principles of a complementary forage system (Farina et al., 2011) and high yielding forages may provide an opportunity to grow more feed in a small area compared to traditional pastures (e.g. 17 $\mathrm{t}$ dry matter $[\mathrm{DM}] / \mathrm{ha}$ ) (Garcia et al., 2007a) thereby reducing average walking distances. Analysis of two years of historical data from a pasture-based AMS research herd has indicated the number of extended milking intervals (>16 h intervals between consecutive milkings) was increased when cows were grazing paddocks in excess of $800 \mathrm{~m}$ from the dairy. The extended milking intervals were also associated with a reduced milk accumulation rate in the udder (Lyons et al., 2014).

Recent developments with AMS technology have resulted in installation, testing and co-development of a prototype robotic rotary (RR; Automatic Milking Rotary, DeLaval AMR, Tumba, Sweden) which is expected to have the capacity to milk up to 800 cows when it is commercialized (Kolbach et al., 2012). The RR has the potential to be used with either batch milking or voluntary cow traffic. If the RR is to be used with voluntary cow traffic, it will likely be adopted with herds much larger in size than any existing pasture-based AMS. With the imminent commercialization of the RR (DeLaval AMR, Sweden) it is important for research to address some of the potential challenges that may be associated with voluntary trafficking of large pasture-based herds. One of those challenges is the longer distances to pasture that will be inevitable with the larger herds. Developing robust management practices within an AMS system is important to ensure that farmers have the best opportunity to be successful when AMS is adopted on-farm (Donohue et al., 2010). One approach is to increase the amount of grazeable forages within a $1-\mathrm{km}$ radius of the dairy.

Strategic selection of high yielding grazeable forages in different seasons that have high growth and/or re-growth potential in summer (e.g. maize, soybean, sorghum) or in autumn-winter (e.g. forage rape, ryegrass) has the potential to dramatically increase the yield of forages compared to current levels of pasture utilization (14 to $20 \mathrm{t} \mathrm{DM} / \mathrm{ha}$; Stockdale, 1983; Garcia et al., 2007b). Previous research has shown that sowing soybean in late-spring and forage rape in late-summer may provide 8 to $10 \mathrm{t} \mathrm{DM}$ /ha (Islam and Garcia, unpubl. results) and 11 to $14 \mathrm{t} \mathrm{DM/ha} \mathrm{(Garcia} \mathrm{et}$ al., 2008; Islam and Garcia, 2012; Islam et al., 2012a) respectively in three harvests. Ryegrass (short season) can also provide 13 to $14 \mathrm{t} \mathrm{DM} /$ ha in 7 to 8 harvests (Neal et al., 2009). However, yield of these forages and water requirements may vary due to climatic variations such as El-Nino Southern Oscillation (ENSO) events (Chauhan, 2010) which need to be investigated. It was hypothesized that using these forages in rotations individually, or by intercropping or over-sowing may increase grazeable forage supply for AMS herds substantially. Various work reported advantages of intercropping in terms of yield, nutrient-use efficiency and in controlling weeds, pests and diseases (Ofori and Stern, 1987; Caviglia et al., 2004).

Therefore, a modelling study was undertaken in order to investigate the potentials of APSIM to screen forages that can be grown to supply a high yield of grazeable forages for large AMS herds. The expected output of this study was to gather information on different options of forage crops for AMS farms potential yield and optimum growing season of such forages and alleviate risks. The main objective of this APSIM modelling was to develop sustainable forage option technologies tailored to AMS dairy farming systems.

\section{MATERIALS AND METHODS}

\section{Simulation model}

The model used in this study (APSIM version 7.0) is a crop simulation model (Keating et al., 2003) consisting of modules that incorporate aspects of soil nitrogen $(\mathrm{N})$, water, crop residues, crop growth and development, and their interactions within a cropping system that is driven by daily weather data. It calculates the potential yield, which is the maximum yield reached by a crop in a given environment that is not limited by pests, diseases, frost damage, weeds and lodging, but is limited by temperature, solar radiation, $\mathrm{N}$ and water supply (Asseng et al., 2008). The model is calibrated, tested and validated in different locations and is extensively used in Australia and internationally (Robertson et al., 2005; Anwar et al., 2009; Chauhan, 2010; Pembleton et al., 2011) to simulate yield of many grain and forage crops individually and in rotations with various input rates for $\mathrm{N}$ and water under various sowing management strategies. The above mentioned publications reported their assessed model predictions against field trials using a range of soil, crop, climatic and management data and have concluded that the APSIM model is able to adequately simulate crops and forages growth. More recently, the capability of the model to simulate triple-crop annual rotations has been confirmed (Islam and Garcia, 2010).

\section{Site, soil and climate}

The chosen study site was Camden, located $\left(150.70^{\circ} \mathrm{E}\right.$, $34.05^{\circ} \mathrm{S}$ ) in New South Wales, Australia. Camden is the location of Australia's first and only pasture-based AMS research herd. Annual average rainfall of this site was 737.7 mm (1900 to 2010), with a diverse annual range from 324 (1944) to $1,542 \mathrm{~mm}$ (1950). Rainfall is generally quite evenly dispersed through the 12-month period. On average, rainfall in spring (September to November), summer (December to February), autumn (March to May) and winter (June to August) accounted for 24.1\%, 27.8\%, 20.8\%, and $28.6 \%$ of the annual rainfall, respectively. Mean annual 
Table 1. Soil properties at the Camden study site used in simulation modules in APSIM

\begin{tabular}{lcccccccccc}
\hline $\begin{array}{c}\text { Depth } \\
(\mathrm{cm})\end{array}$ & $\begin{array}{c}\text { BD } \\
(\mathrm{g} / \mathrm{cc})\end{array}$ & $\begin{array}{c}\text { SAT } \\
(\mathrm{mm} / \mathrm{mm})\end{array}$ & $\begin{array}{c}\text { DUL } \\
(\mathrm{mm} / \mathrm{mm})\end{array}$ & $\begin{array}{c}\text { AirDry } \\
(\mathrm{mm} / \mathrm{mm})\end{array}$ & $\begin{array}{c}\mathrm{LL} \\
(\mathrm{mm} / \mathrm{mm})\end{array}$ & $\begin{array}{c}\text { PAWC } \\
(\mathrm{mm})\end{array}$ & $\begin{array}{c}\text { Organic } \\
\text { carbon }(\%)\end{array}$ & $\begin{array}{c}\mathrm{pH} \\
(\text { water })\end{array}$ & $\begin{array}{c}\mathrm{SW} \\
(\%)\end{array}$ & $\begin{array}{c}\mathrm{NO}_{3}-\mathrm{N} \\
(\mathrm{kg} / \mathrm{ha})\end{array}$ \\
\hline 0 to 15 & 1.29 & 0.48 & 0.29 & 0.05 & 0.10 & 29.7 & 1.37 & 6.3 & 9.5 & 0.19 \\
15 to 30 & 1.63 & 0.36 & 0.29 & 0.12 & 0.16 & 20.6 & 0.43 & 6.3 & 15.5 & 0.24 \\
30 to 60 & 1.40 & 0.44 & 0.39 & 0.24 & 0.24 & 46.2 & 0.33 & 6.8 & 23.8 & 0.42 \\
60 to 90 & 1.44 & 0.43 & 0.38 & 0.23 & 0.23 & 44.7 & 0.24 & 7.7 & 22.8 & 0.43 \\
90 to 120 & 1.55 & 0.39 & 0.34 & 0.23 & 0.23 & 33.0 & 0.15 & 8.2 & 22.7 & 0.46 \\
120 to 150 & 1.68 & 0.34 & 0.29 & 0.21 & 0.21 & 23.7 & 0.11 & 8.3 & 20.9 & 0.50 \\
150 to 180 & 1.72 & 0.32 & 0.27 & 0.21 & 0.21 & 18.6 & 0.11 & 8.2 & 21.0 & 0.52 \\
\hline
\end{tabular}

APSIM, Agricultural Production Systems Simulator; BD, bulk density; SAT, saturated water content; DUL, drained upper limit of soil water content; LL, lower limit of soil water content; PAWC, plant available water capacity; $\mathrm{SW}$, soil water; $\mathrm{NO}_{3}-\mathrm{N}$, nitrate-nitrogen.

minimum and maximum temperature were $10.7^{\circ} \mathrm{C}$ and $23.3^{\circ} \mathrm{C}$, respectively and mean average radiation was 16.9 $\mathrm{MJ} / \mathrm{m}^{2}$.

Simulations were conducted using the APSIM model with historical weather data from 1900 to 2010, which was downloaded from the enhanced climate database SILO (www.longpaddock.qld.gov.au/silo). The model used inputs of minimum and maximum temperatures, rainfall, solar radiation and vapour pressure deficit on a daily time step every year to simulate growth and yield of forages used in the rotation. The soil of the site corresponded to brown chromosols and black vertisol (Isbell, 2002), which was loam over clay, with texture ranging from loam on surface layers (0 to $15 \mathrm{~cm})$ to heavy clay from 30 to $120 \mathrm{~cm}$ and to light clay below $120 \mathrm{~cm}$. Soil properties in the simulated site are given in Table 1.

\section{Simulation scenarios and model criteria}

The aim of this study was to investigate and identify forage crops options with regard to their suitability for AMS herds through APSIM simulations. These crop rotations were intended as potential options that may provide forages throughout the year and enable field researchers to make tailored decisions on which forage option(s) may be suitable for AMS herds.

In order to investigate impact of different forage options that can supply maximum forages to AMS herds throughout the year, three main rotational forage options simulations were carried out. These were: i) maize, ii) soybean, and iii) sorghum as summer forages each followed by forage rape over-sown or intercropped with ryegrass to complete a yearround rotation. There are no existing modules to simulate forage rape and ryegrass using APSIM. However, previous work (Islam and Garcia, 2010) have indicated that the canola and weed modules of APSIM can closely simulate yields of forage rape and ryegrass, respectively. Whilst Sorghum does exist in the APSIM module, its simulated regrowth is limited. However, it was found that SweetSorghum modules in APSIM simulations generate regrowth, which was more representative of re-growth achieved in the field. As a result the modules of APSIM maize, canola, weed and SweetSorghum were used to simulate yields of maize, forage rape, ryegrass and sorghum, respectively.

Each of the forage crops were simulated over the years from 1900 to 2010. Long term average values of monthly simulated growth rate $(\mathrm{kg} / \mathrm{ha} / \mathrm{d})$ for each forage in the rotation were used to calculate total simulated yield. Risks associated with ENSO events particularly due to El-Nino were also assessed. Data dispersion among years or differences due to climate was used for risk assessment or probability of not achieving a certain target.

Irrigation was non-limiting in all simulations and efficiency of irrigation was set at 1 . Initial surface residue was set at $1,000 \mathrm{~kg} / \mathrm{ha}$ and carbon:nitrogen $(\mathrm{C}: \mathrm{N})$ ratio of initial residue was 80 . Details of agronomic principles used in each of the three rotation simulations are provided below and presented in Table 2 and 3.

Maize followed with forage rape and ryegrass (oversown with forage rape) : Maize was sown in simulations in four different sowing dates with a fixed rate $\mathrm{N}$ fertilizer (135 kg/ha) applied at the time of sowing. Simulated sowing dates were 10 October, 20 October, 20 November and 20 December. All maize crop sowing treatments were grazed (harvested in simulations) at Zadoks growth scale 8 (Zadoks et al., 1974). After the final grazing of maize, forage rape was sown respectively in maize sowing treatments on 15 February, 20 February, 28 February and 7 March in the four maize sowing treatments respectively. Ryegrass was over-sown with forage rape immediately after first grazing and second grazing simulations respectively after first two and last two sowing dates (Table 2). Final grazing of forage rape in all simulations occurred on 13 August to allow high growth of ryegrass. Forage rape was grazed when simulated yield reached 4.5 t/ha or over. Three to four grazings were achieved from forage rape. A total of $70 \mathrm{~kg} \mathrm{~N} / \mathrm{ha}$ was applied to forage rape at the time of sowing, $90 \mathrm{~kg} \mathrm{~N} / \mathrm{ha}$ after the $1 \mathrm{st}$ grazing and $70 \mathrm{~kg} \mathrm{~N} / \mathrm{ha}$ thereafter after each subsequent grazing (Islam and Garcia, 2012). Thus, a total of $300 \mathrm{~kg} \mathrm{~N} / \mathrm{ha}$ was applied to forage rape. On 
Table 2. Sowing dates and rates and timing of $\mathrm{N}$ fertiliser and harvesting dates of forages in the rotations used in simulations

\begin{tabular}{|c|c|c|c|c|c|c|c|c|c|c|c|c|c|c|c|c|c|c|c|c|}
\hline \multirow{4}{*}{$\begin{array}{l}\text { Simula- } \\
\text { tions }^{1}\end{array}$} & \multicolumn{7}{|c|}{ Summer forages } & \multicolumn{12}{|c|}{ Autumn-winter-spring forages } & \multirow{4}{*}{$\begin{array}{r}\text { Total N } \\
-(\mathrm{kg} / \mathrm{ha})\end{array}$} \\
\hline & \multirow{3}{*}{$\begin{array}{c}\text { Sowing } \\
\text { date }\end{array}$} & \multicolumn{5}{|c|}{$\mathrm{N}$ application $(\mathrm{A})$ timing and rate $(\mathrm{kg} / \mathrm{ha})$} & \multirow{3}{*}{ Harvest $^{2}$} & \multirow{2}{*}{\multicolumn{2}{|c|}{ Sowing date }} & \multicolumn{8}{|c|}{$\mathrm{N}$ application (A) timing and rate $(\mathrm{kg} / \mathrm{ha})$} & \multirow{2}{*}{\multicolumn{2}{|c|}{ Harvest ${ }^{4}$}} & \\
\hline & & \multirow{2}{*}{$\begin{array}{c}\text { A1 } \\
\text { At sowing }\end{array}$} & \multicolumn{2}{|c|}{ A2 } & \multicolumn{2}{|c|}{$\mathrm{A} 3$} & & & & \multicolumn{2}{|c|}{ A1 } & \multicolumn{2}{|c|}{$\mathrm{A} 2$} & \multicolumn{2}{|c|}{$\mathrm{A} 3$} & \multicolumn{2}{|c|}{ A4 } & & & \\
\hline & & & Date & Rate & Date & Rate & & $\begin{array}{c}\text { Forage } \\
\text { rape }\end{array}$ & $\begin{array}{l}\text { Rye- } \\
\text { grass }^{3}\end{array}$ & Date & Rate & Date & Rate & Date & Rate & Date & Rate & $\begin{array}{c}\text { Forage } \\
\text { rape }\end{array}$ & $\begin{array}{l}\text { Rye- } \\
\text { grass }^{3}\end{array}$ & \\
\hline M1 & $10-$ Oct & 135 & & & & & $14-\mathrm{Feb}$ & $15-\mathrm{Feb}$ & 28-Apr & 16-Feb & 70 & $\begin{array}{l}27- \\
\text { Apr }\end{array}$ & 90 & $\begin{array}{l}26- \\
\text { Jun }\end{array}$ & 70 & $\begin{array}{c}26- \\
\text { Aug }\end{array}$ & 70 & 13-Aug & $\begin{array}{l}9- \\
\text { Oct }\end{array}$ & 435 \\
\hline M2 & 20-Oct & 135 & & & & & 19-Feb & $20-\mathrm{Feb}$ & 28-Apr & 21-Feb & 70 & $\begin{array}{l}27- \\
\text { Apr }\end{array}$ & 90 & $\begin{array}{l}26- \\
\text { Jun }\end{array}$ & 70 & $\begin{array}{l}26- \\
\text { Aug }\end{array}$ & 70 & 13-Aug & $\begin{array}{l}19- \\
\text { Oct }\end{array}$ & 435 \\
\hline M3 & 20-Nov & 135 & & & & & 27-Feb & 28-Feb & 26-Jun & 27-Feb & 70 & $\begin{array}{l}27- \\
\text { Apr }\end{array}$ & 90 & $\begin{array}{l}\text { 26- } \\
\text { Jun }\end{array}$ & 70 & $\begin{array}{l}\text { 26- } \\
\text { Aug }\end{array}$ & 70 & 13-Aug & $\begin{array}{l}19- \\
\text { Nov }\end{array}$ & 435 \\
\hline M4 & 20-Dec & 135 & & & & & 6-Mar & 7-Mar & 19-Jul & 7-Mar & 70 & $\begin{array}{l}\text { 19- } \\
\text { May }\end{array}$ & 90 & $\begin{array}{l}19- \\
\text { Jul }\end{array}$ & 70 & $\begin{array}{l}19- \\
\text { Sep }\end{array}$ & 70 & 13-Aug & $\begin{array}{c}1- \\
\text { Dec }\end{array}$ & 435 \\
\hline S1 & 15-Oct & 0 & & 0 & & & 19-Feb & 20-Feb & 1-Apr & 21-Feb & 70 & $\begin{array}{l}1- \\
\text { Apr }\end{array}$ & 70 & $\begin{array}{l}1- \\
\text { Jun }\end{array}$ & 70 & $\begin{array}{c}1- \\
\text { Aug }\end{array}$ & 70 & 14-Oct & $\begin{array}{l}14- \\
\text { Oct }\end{array}$ & 280 \\
\hline S2 & 15-Nov & 0 & & 0 & & & 14-Mar & 15-Mar & 1-May & 16-Mar & 70 & $\begin{array}{c}1- \\
\text { May }\end{array}$ & 70 & $\begin{array}{l}1- \\
\text { Jul }\end{array}$ & 70 & 1-Sep & 70 & 14-Oct & $\begin{array}{l}14- \\
\text { Nov }\end{array}$ & 280 \\
\hline S3 & 30-Nov & 0 & & 0 & & & 24-Mar & 25-Mar & 25-May & 26-Mar & 70 & $\begin{array}{l}25- \\
\text { May }\end{array}$ & 70 & $\begin{array}{l}25- \\
\text { Jul }\end{array}$ & 70 & $\begin{array}{l}25- \\
\text { Sep }\end{array}$ & 70 & 14-Oct & $\begin{array}{l}29- \\
\text { Nov }\end{array}$ & 280 \\
\hline S4 & 15-Dec & 0 & & 0 & & & 30-Mar & 31-Mar & 31-May & 1-Apr & 70 & $\begin{array}{c}31- \\
\text { May }\end{array}$ & 70 & $\begin{array}{l}30- \\
\text { Jul }\end{array}$ & 70 & $\begin{array}{l}30- \\
\text { Sep }\end{array}$ & 70 & 14-Oct & $\begin{array}{l}29- \\
\text { Nov }\end{array}$ & 280 \\
\hline $\mathrm{Sg} 1$ & 1-Nov & 40 & 7-Jan & 40 & $25-\mathrm{Feb}$ & 40 & 30-Apr & 1-May & 1-May & 2-May & 70 & $\begin{array}{l}5- \\
\text { Jul }\end{array}$ & 70 & $\begin{array}{l}15- \\
\text { Sep }\end{array}$ & 70 & & & 31-Oct & $\begin{array}{l}31- \\
\text { Oct }\end{array}$ & 330 \\
\hline $\mathrm{Sg} 2$ & 15-Nov & 40 & 7-Jan & 40 & $25-\mathrm{Feb}$ & 40 & 30-Apr & 1-May & 1-May & 2-May & 70 & $\begin{array}{l}5- \\
\text { Jul }\end{array}$ & 70 & $\begin{array}{l}15- \\
\text { Sep }\end{array}$ & 70 & & & 14-Nov & $\begin{array}{l}14- \\
\text { Nov }\end{array}$ & 330 \\
\hline $\mathrm{Sg} 3$ & 30-Nov & 40 & 15-Jan & 40 & $25-\mathrm{Feb}$ & 40 & 30-Apr & 1-May & 1-May & 2-May & 70 & $\begin{array}{l}5- \\
\text { Jul }\end{array}$ & 70 & $\begin{array}{l}15- \\
\text { Sep }\end{array}$ & 70 & & & 29-Nov & $\begin{array}{l}29- \\
\text { Nov }\end{array}$ & 330 \\
\hline $\mathrm{Sg} 4$ & 15-Dec & 40 & 15-Jan & 40 & $25-\mathrm{Feb}$ & 0 & 30-Apr & 1-May & 1-May & 2-May & 70 & $\begin{array}{l}5- \\
\text { Jul }\end{array}$ & 70 & $\begin{array}{l}15- \\
\text { Sep }\end{array}$ & 70 & & & 14-Dec & $\begin{array}{l}14- \\
\text { Dec }\end{array}$ & 290 \\
\hline
\end{tabular}

${ }^{1} \mathrm{M}, \mathrm{S}$, and $\mathrm{Sg}$ represents maize, soybean and sorghum respectively each followed by a intercrop of forage rape-ryegrass (weed) rotation and $1,2,3$, and 4 against each of M,S, and Sg represents as sowing 1, sowing 2, sowing 2, and sowing 4 respectively.

${ }^{2}$ Maize harvested at Zadoks growth stage 8 .

${ }^{3}$ Weed as ryegrass.

${ }^{4}$ Forage rape harvested at pre-graze cover of $\geq 4.5 \mathrm{t} \mathrm{DM} /$ ha and ryegrass as weed harvested at pre-graze cover of $\geq 2 \mathrm{t} \mathrm{DM} / \mathrm{ha}$.

the other hand, ryegrass was grazed when the simulated yield reached $2 \mathrm{t} / \mathrm{ha}$ or over. No additional $\mathrm{N}$ was applied to ryegrass since $300 \mathrm{~kg} \mathrm{~N} / \mathrm{ha}$ applied to forage rape by default was in fact used by forage rape-ryegrass. The final grazing of ryegrass was made a day before the next sowing of maize to start the rotation again.

Soybean followed with forage rape and ryegrass (oversown with forage rape) : Soybean was also sown in simulations on four different sowing dates, but no $\mathrm{N}$ fertilizer was applied at the time of sowing or thereafter.
Sowing dates were 15 October, 15 November, 30 November and 15 December. In all sowing treatments, soybeans were harvested when they reached yields exceeding $4.5 \mathrm{t} / \mathrm{ha}$ or over. In most simulations soybeans were grazed three times. Final grazings of soybeans were carried out on 19 February, 14 March, 24 March and 30 March, respectively for the above mentioned sowing dates. Forage rape was sown one day after grazing of soybean in all sowing treatments. Ryegrass was over-sown with forage rape immediately after first grazing of forage rape in all sowings of forage rape. A

Table 3. Agronomy and management rules used in simulations ${ }^{1}$ during the periods from 1900 through 2010

\begin{tabular}{|c|c|c|c|c|c|}
\hline Parameters & Maize & Soybean & $\begin{array}{c}\text { Sorghum as } \\
\text { SweetSorghum }\end{array}$ & $\begin{array}{c}\text { Forage rape as } \\
\text { Canola }\end{array}$ & Ryegrass as weed \\
\hline Cultivar & Pioneer 3527 & Davis & Sugargraze & Early & Late \\
\hline \multicolumn{6}{|l|}{ Sowing characteristics } \\
\hline Plants/sq.m. & 10 & 30 & 16 & 80 & 100 \\
\hline Row spacing (cm) & 65 & 17 & 65 & 17 & 17 \\
\hline Sowing depth $(\mathrm{cm})$ & 4.5 & 3.0 & 3.0 & 2.0 & 1.5 \\
\hline Harvesting & $\begin{array}{l}\text { Zadoks scale } 8 \text { or } \\
\text { day } 59 \text {; harvest } \\
\text { height } 20 \mathrm{~cm}\end{array}$ & $\begin{array}{l}\text { When crop } \\
\text { reached } 4.5 \mathrm{t} \\
\mathrm{DM} / \mathrm{ha} \text {; harvest } \\
\text { height } 35 \mathrm{~cm}\end{array}$ & $\begin{array}{l}\text { When crop reached } \\
4.5 \mathrm{t} \mathrm{DM} / \mathrm{ha} \text {; harvest } \\
\text { height } 35 \mathrm{~cm}\end{array}$ & $\begin{array}{l}\text { When crop } \\
\text { reached } 4.5 \mathrm{t} \\
\text { DM/ha; harvest } \\
\text { height } 35 \mathrm{~cm}\end{array}$ & $\begin{array}{l}\text { When crop reached } \\
2 \mathrm{t} \mathrm{DM} / \mathrm{ha} \text {; harvest } \\
\text { height } 5 \mathrm{~cm}\end{array}$ \\
\hline
\end{tabular}

\footnotetext{
${ }^{1}$ Irrigation water was non-limiting as automatic irrigation in simulation was on; efficiency of irrigation was set at 1 ; initial surface residue was set at
} $1,000 \mathrm{~kg} / \mathrm{ha}$ and $\mathrm{C}: \mathrm{N}$ ratio of initial residue was $80 ; 0.90$ removed from all crops when harvested at grazing. 
total of $280 \mathrm{~kg} \mathrm{~N} / \mathrm{ha}$ was applied to forage rape; $70 \mathrm{~kg} \mathrm{~N} / \mathrm{ha}$ at the time of sowing and $70 \mathrm{~kg} \mathrm{~N} / \mathrm{ha}$ after each harvest. No $\mathrm{N}$ fertilizer was applied to specifically to ryegrass as it was planted as a companion to the forage rape. The grazing rules for forage rape and ryegrass were the same as described in maize rotations above. The final grazing of each of the forage rape-ryegrass was made a day before the next sowing of soybean to start the rotation again.

Sorghum followed with forage rape and ryegrass (intercropped) : SweetSorghum was sown in simulations on four sowing dates (1 November, 15 November, 30 November and 15 December). The final grazing date of sorghum (in all sowing date simulations) was 30 April.

A fixed final grazing date applied to sorghum treatment simulations was set in recognition of the high frost risk after 30 April. The 1 November sowing date simulation achieved two to three grazings whereas the last sowing simulation (15 December) was able to achieve a maximum of only two grazings prior to 30 April. Whilst the final grazing date of 30 April was suited to the sorghum, it resulted in the optimum sowing date for the forage rape-ryegrass being compromised. Nitrogen fertilizer was applied at $40 \mathrm{~kg} \mathrm{~N} / \mathrm{ha}$ after each sorghum grazing. Therefore, in the first three sowing treatments, $\mathrm{N}$ fertilizer was applied up to three times (total $120 \mathrm{~kg} / \mathrm{ha}$ ), but only twice in the last sowing treatment (total $80 \mathrm{~kg} / \mathrm{ha}$ ).

The forage rape-ryegrass was sown on 1 May in all sorghum simulations. The final grazings were carried out on
31 October, 14 November, 29 November and 14 December to coincide with the 4 sowing dates for the subsequent season of sorghum (Table 2). In all treatments, only two grazings of forage rape was possible. Nitrogen was applied at $140 \mathrm{~kg} / \mathrm{ha}$ in all sowing simulations; $70 \mathrm{~kg} \mathrm{~N} / \mathrm{ha}$ at the time of sowing and $70 \mathrm{~kg} \mathrm{~N} / \mathrm{ha}$ after the 1st grazing of forage rape. No $\mathrm{N}$ fertilizer was applied directly to the ryegrass in the simulation. Grazing management of forage rape and ryegrass was the same as described for these forages in the maize and soybean rotations (see previous sections).

\section{Approaches used for model validation}

Local yield data of individual forages (used in rotation simulations) generated in field experiments at Camden were used to simulate the growing conditions observed in the field (Table 4). In addition, our experiences on field experiments (Garcia and Fulkerson, 2005; Garcia et al., 2006; 2007a, b; 2008; Fariña et al., 2011; Islam and Garcia, 2012) on annual cycle of a triple-crop CFR including simulations and validation of CFR using a range of $\mathrm{N}$ ( 0 to $523 \mathrm{~kg} / \mathrm{ha}$ ) and water (0 to $14 \mathrm{ML} / \mathrm{ha}$ ) (Islam and Garcia 2010) and experimental data on triple-crop CFR rotations have created a level of confidence within the authors that APSIM is a suitable tool allowing the simulation and screening of potential grazeable forage rotations for AMS herds. However, it should be mentioned that the forage screening simulation rotations for AMS herds used in this

Table 4. Actual and simulated ${ }^{1}$ data used for validation of the model

\begin{tabular}{|c|c|c|c|c|c|c|c|c|c|c|c|c|}
\hline & \multirow[b]{2}{*}{ Crop } & \multirow{2}{*}{$\begin{array}{l}\text { Compo- } \\
\text { nents }\end{array}$} & \multicolumn{6}{|c|}{ Actual } & \multicolumn{4}{|c|}{ Simulated } \\
\hline & & & Sowing date & Final harvest & $\begin{array}{c}\text { Irriga- } \\
\text { tion }\end{array}$ & $\begin{array}{c}\mathrm{N}^{\mathrm{a}} \\
\mathrm{kg} / \mathrm{ha}\end{array}$ & $\begin{array}{c}\text { Yield } \\
\text { (t DM/ha) }\end{array}$ & Cultivars & $\begin{array}{l}\text { Plants/ } \\
\text { sq.m. }\end{array}$ & $\begin{array}{c}\text { Yield } \\
(\mathrm{t} \text { DM/ha })^{1}\end{array}$ & $\begin{array}{c}\text { Row spacing, } \\
\mathrm{m}\end{array}$ & $\begin{array}{c}\text { Simulated } \\
\text { cultivars }\end{array}$ \\
\hline Islam and & Soybean only & & $19 / 11 / 2010$ & $14 / 04 / 2011$ & Full & $240^{c}$ & 8.3 & Intrepid & 30 & 10.2 & 0.17 & Davis \\
\hline \multirow[t]{7}{*}{ Garcia $(2014)^{\mathrm{d}}$} & Soybean only & & $19 / 11 / 2010$ & $14 / 04 / 2011$ & 0 & $240^{c}$ & 5.8 & Intrepid & 30 & 7.8 & 0.17 & Davis \\
\hline & Soybean only & & $19 / 12 / 2008$ & 20/02/2009 & Full & $240^{c}$ & 5.1 & Intrepid & 30 & 6.2 & 0.17 & Davis \\
\hline & Soybean only & & $19 / 11 / 2010$ & $14 / 04 / 2011$ & Full & $240^{c}$ & 7.7 & Warrigal & 30 & 10.2 & 0.17 & Davis \\
\hline & Soybean only & & $19 / 11 / 2010$ & $14 / 04 / 2011$ & 0 & $240^{c}$ & 6.8 & Warrigal & 30 & 7.8 & 0.17 & Davis \\
\hline & Soybean only & & $19 / 11 / 2010$ & $14 / 04 / 2011$ & Full & $240^{c}$ & 8.7 & Zeus & 30 & 10.2 & 0.17 & Davis \\
\hline & Maize only & & $22 / 02 / 2009$ & $23 / 04 / 2009$ & Full & 101 & 5.6 & $31 \mathrm{H} 50$ & 13 & 4.2 & 0.65 & Pioneer 3527 \\
\hline & Maize only & & $2 / 02 / 2010$ & $1 / 04 / 2010$ & Full & 135 & 7.0 & $31 \mathrm{H} 50$ & 13 & 5.0 & 0.65 & Pioneer 3527 \\
\hline \multirow[t]{2}{*}{$\begin{array}{l}\text { Islam and } \\
\text { Garcia (2009) }\end{array}$} & $\begin{array}{c}\text { Maize-forage rape } \\
\text { (FR) }\end{array}$ & Maize & $22 / 02 / 2009$ & $23 / 04 / 2009$ & Full & 101 & 5.5 & $31 \mathrm{H} 50$ & 12 & 5.0 & 0.65 & Pioneer 3527 \\
\hline & & FR & $22 / 02 / 2009$ & $24 / 09 / 2009$ & Full & 300 & 12.4 & Goliath & 80 & 10.3 & 0.17 & Early (Canola) \\
\hline Islam and & Maize-Ryegrass & Maize & $22 / 02 / 2009$ & $23 / 04 / 2009$ & Full & 101 & 5.9 & $31 \mathrm{H} 50$ & 12 & 4.0 & 0.65 & Pioneer 3527 \\
\hline \multirow[t]{3}{*}{ Garcia (2013) } & & Ryegrass & $22 / 02 / 2009$ & $24 / 09 / 2009$ & Full & 100 & 5.4 & Surrey & 100 & 6.6 & 0.17 & As weed (Early) \\
\hline & Maize-FR & Maize & $2 / 02 / 2010$ & $1 / 04 / 2010$ & Full & 140 & 6.9 & $31 \mathrm{H} 50$ & 12 & 4.8 & 0.65 & Pioneer 3527 \\
\hline & & FR & $2 / 04 / 2010$ & $12 / 10 / 2010$ & Full & 250 & 11.8 & Goliath & 80 & 11.0 & 0.17 & Early (Canola) \\
\hline $\begin{array}{l}\text { Garcia et al. } \\
(2008)^{\mathrm{b}}\end{array}$ & $\begin{array}{c}\text { Maize-FR-Maple } \\
\text { pea }\end{array}$ & FR & $20 / 02 / 2004$ & 24/09/2004 & Full & 270 & 11.4 & Goliath & 80 & 10.0 & 0.17 & Early (Canola) \\
\hline $\begin{array}{l}\text { Pancha and } \\
\text { Garcia }(2008)^{\mathrm{d}}\end{array}$ & Soybean only & & $21 / 11 / 2007$ & $2 / 02 / 2008$ & Full & 0 & 7.9 & Intrepid & 80 & 7.5 & 0.17 & Davis \\
\hline $\begin{array}{l}\text { Horadagoda and } \\
\text { Garcia }(2011)^{\mathrm{d}}\end{array}$ & Soybean only & & $12 / 12 / 2008$ & $22 / 02 / 2009$ & Full & 27 & 9.1 & Intrepid & 80 & 7.8 & 0.17 & Davis \\
\hline
\end{tabular}

FR, forage rape; CFR, complementary forage rotation.

${ }^{1}$ Every simulation covered periods from 1900 through 2010.

${ }^{a}$ Rates of $\mathrm{N}$ fertiliser was the same as observed except for ryegrass which was simulated without $\mathrm{N}$.

${ }^{\mathrm{b}}$ FR was grown in a rotation of CFR over three years.

${ }^{\mathrm{c}}$ DAP (Di-ammonium phosphate) contained $18 \%$ N, 20\% P, and 2.2\% sulphur (Hi-fert, Melbourne, Victoria).

${ }^{\mathrm{d}}$ Unpublished results. 
study have not been tested in any field studies nor have they been reported.

\section{RESULTS}

\section{Comparison of modelled and actual yield of individual forages used in the rotation}

Actual historical yield data of individual forages (used in the rotation simulations) was predicted relatively moderately $\left(\mathrm{R}^{2}=0.58\right)$ by the simulated yield of the respective individual forages (Figure 1; Table 4).

\section{Grazeable forage options and simulated yields from different rotation options}

Maize and forage rape-ryegrass rotations provided simulated yields of a total of 28.2,27.8, 26.0, and $25.3 \mathrm{t}$ $\mathrm{DM} / \mathrm{ha}$ grazeable forages respectively for 10 October, 20 October, 20 November and 20 December sowing treatments (Table 5). There was a consistent trend of maize yield declining as the sowing date progressed from 10 October to 20 December. As sowing dates for forage rape over-sown with ryegrass progressed the simulated yield of forage rape decreased from 10.0 to $8.2 \mathrm{t} \mathrm{DM} / \mathrm{ha}$ but this coincided with ryegrass yields increasing from 5.8 to $6.5 \mathrm{t} \mathrm{DM} / \mathrm{ha}$. The increased ryegrass yields were insufficient to counteract the decrease in forage rape yields resulting in overall simulated yields of late sowing of forage rape-ryegrass combinations decreasing from $15.8 \mathrm{t} \mathrm{DM} / \mathrm{ha}$ to $14.7 \mathrm{t} \mathrm{DM} / \mathrm{ha}$. As a result of decrease of yields of both maize and forage rape-ryegrass, total simulated grazeable forage yields from this rotation also decreased due to late sowing (Table 5).

Total grazeable simulated yields from soybean-based rotations were $22.9,22.9,22.4$, and $21.5 \mathrm{t} \mathrm{DM} / \mathrm{ha}$

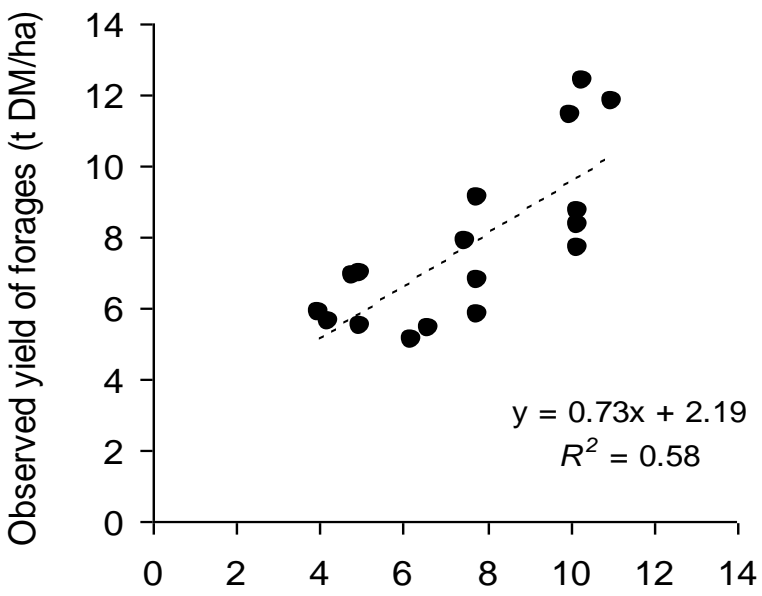

\section{Simulated yield of forages (t DMha)}

Figure 1. Prediction of actual (observed) yield of forages grown either individually or in intercrop from respective simulated yields (data can be seen in Table 4).

respectively for 15 October, 15 November, 30 November and 15 December sowing (Table 5). The pattern of decrease in soybean ( 9.5 to $7.6 \mathrm{t} \mathrm{DM} / \mathrm{ha}$ ) and forage rape (8.3 to $7.9 \mathrm{t}$ $\mathrm{DM} / \mathrm{ha}$ ), and increase in ryegrass (5.1 to $6.0 \mathrm{t} \mathrm{DM} / \mathrm{ha})$ in soybean-based rotations due to late sowing was similar to the maize-based rotations. However, simulated yields of both forage rape and ryegrass in soybean-based rotations were lower compared to those obtained from maize-based rotations.

As a consequence of the limited number of simulated grazings of sorghum (particularly in late sowings) combined with the late sowing of forage rape-ryegrass, total simulated grazeable forage yields were 19.3, 19.1, 19.1, and

Table 5. Simulated forage yields (t DM/ha) in rotations of maize, soybean and sorghum sown in summer followed by forage rape (oversown or intercropped) with ryegrass

\begin{tabular}{|c|c|c|c|c|c|c|}
\hline \multirow{3}{*}{ Rotations } & \multirow{3}{*}{ Simula-tions ${ }^{1}$} & \multicolumn{4}{|c|}{ Simulated forage yields (t DM/ha) } & \multirow{3}{*}{$\begin{array}{l}\text { Total simulated forages } \\
\text { (t DM/ha/yr) (SD) }\end{array}$} \\
\hline & & \multirow{2}{*}{$\mathrm{M} / \mathrm{S} / \mathrm{Sg}^{1}$} & \multicolumn{3}{|c|}{ Forage rape-ryegrass intercrop } & \\
\hline & & & Forage rape & Ryegrass & Total & \\
\hline \multirow[t]{4}{*}{ Maize } & M1 & 12.4 & 10.0 & 5.8 & 15.8 & $28.2(1.7)$ \\
\hline & M2 & 12.1 & 9.5 & 6.2 & 15.7 & $27.8(1.6)$ \\
\hline & M3 & 11.3 & 8.5 & 6.2 & 14.7 & $26.0(1.7)$ \\
\hline & M4 & 10.6 & 8.2 & 6.5 & 14.7 & $25.3(1.5)$ \\
\hline \multirow[t]{4}{*}{ Soybean } & $\mathrm{S} 1$ & 9.5 & 8.3 & 5.1 & 13.4 & $22.9(0.9)$ \\
\hline & S2 & 9.4 & 8.0 & 5.5 & 13.5 & $22.9(1.0)$ \\
\hline & S3 & 9.0 & 7.9 & 5.5 & 13.4 & $22.4(0.9)$ \\
\hline & S4 & 7.6 & 7.9 & 6.0 & 13.9 & $21.5(1.1)$ \\
\hline \multirow[t]{4}{*}{ Sorghum } & $\mathrm{Sg} 1$ & 10.2 & 4.6 & 4.5 & 9.1 & $19.3(1.3)$ \\
\hline & $\mathrm{Sg} 2$ & 9.7 & 4.6 & 4.8 & 9.4 & $19.1(0.9)$ \\
\hline & $\mathrm{Sg} 3$ & 9.1 & 5.0 & 5.1 & 10.1 & $19.2(0.9)$ \\
\hline & $\mathrm{Sg} 4$ & 6.8 & 4.7 & 5.4 & 10.1 & $16.9(1.7)$ \\
\hline
\end{tabular}

DM, dry matter; SD, standard deviation.

${ }^{1} \mathrm{M}, \mathrm{S}$, and $\mathrm{Sg}$ represents maize, soybean and sorghum respectively each followed by an intercrop of forage rape-ryegrass rotation. Sowing dates and all other agronomic principles can be seen in Table 2. 
Table 6. Simulated monthly mean daily growth rate $(\mathrm{kg} \mathrm{DM} / \mathrm{ha} / \mathrm{d})$ of forages in maize and forage rape oversown with ryegrass at different sowing dates $\left(\mathbf{M}^{1}\right)$

\begin{tabular}{|c|c|c|c|c|c|c|c|c|c|c|c|c|}
\hline & \multicolumn{3}{|c|}{ M1 } & \multicolumn{3}{|c|}{ M2 } & \multicolumn{3}{|c|}{ M3 } & \multicolumn{3}{|c|}{ M4 } \\
\hline & Maize & $\begin{array}{c}\text { Forage } \\
\text { rape }\end{array}$ & $\begin{array}{l}\text { Rye } \\
\text { grass }\end{array}$ & Maize & $\begin{array}{c}\text { Forage } \\
\text { rape }\end{array}$ & $\begin{array}{l}\text { Rye } \\
\text { grass }\end{array}$ & Maize & $\begin{array}{c}\text { Forage } \\
\text { rape }\end{array}$ & $\begin{array}{l}\text { Rye } \\
\text { grass }\end{array}$ & Maize & $\begin{array}{c}\text { Forage } \\
\text { rape }\end{array}$ & $\begin{array}{l}\text { Rye } \\
\text { grass }\end{array}$ \\
\hline Jan & 56.6 & 0 & 0 & 135.2 & 0 & 0 & 265.0 & 0 & 0 & 53.6 & 0 & 0 \\
\hline Feb & 0 & 1.3 & 0 & 0 & 0.7 & 0 & 67.3 & 0 & 0 & 257.4 & 0 & 0 \\
\hline Mar & 0 & 30.3 & 0 & 0 & 20.6 & 0 & 0 & 11.3 & 0 & 36.6 & 4.8 & 0 \\
\hline Apr & 0 & 121.7 & 0 & 0 & 116.4 & 0 & 0 & 85.6 & 0 & 0 & 52.9 & 0 \\
\hline May & 0 & 81.8 & 17.2 & 0 & 79.5 & 17.6 & 0 & 78.7 & 0 & 0 & 97.2 & 0 \\
\hline Jun & 0 & 23.3 & 26.6 & 0 & 35.9 & 29.5 & 0 & 41.0 & 0 & 0 & 52.1 & 0 \\
\hline Jul & 0 & 44.4 & 26.5 & 0 & 39.7 & 24.2 & 0 & 52.3 & 10.3 & 0 & 44.2 & 2.3 \\
\hline Aug & 0 & 25.1 & 34.4 & 0 & 19.7 & 36.3 & 0 & 10.3 & 39.7 & 0 & 18.4 & 30.6 \\
\hline Sep & 0 & 0 & 56.1 & 0 & 0 & 55.1 & 0 & 0 & 52.1 & 0 & 0 & 43.7 \\
\hline Oct & 1.4 & 0 & 30.0 & 0.2 & 0 & 39.8 & 0 & 0 & 67.1 & 0 & 0 & 66.0 \\
\hline Nov & 57.1 & 0 & 0 & 21.7 & 0 & 0 & 0.3 & 0 & 33.0 & 0 & 0 & 69.7 \\
\hline Dec & 291.9 & 0 & 0 & 240.2 & 0 & 0 & 37.4 & 0 & 0 & 0.5 & 0 & 1.8 \\
\hline Grand total & 34.2 & 27.3 & 15.7 & 33.4 & 26.0 & 16.7 & 30.9 & 23.2 & 16.5 & 27.7 & 22.4 & 17.5 \\
\hline
\end{tabular}

${ }^{1} \mathrm{M}$ represents sowing dates of forages. Sowing dates and all other agronomic principles can be seen in Table 2 .

$16.9 \mathrm{t} \mathrm{DM} /$ ha respectively for 15 October, 15 November, 30 November and 15 December sowing of sorghum in sorghum-based rotations (Table 5). Late sowing reduced simulated grazeable sorghum yields substantially.

Standard deviations (based on 111 years) of maize, soybean and sorghum based rotations ranged from 1.5 to $1.7,0.9$ to 1.1 , and 0.9 to $1.7 \mathrm{t} \mathrm{DM} /$ ha, respectively (Table 5), which indicates that under non-limiting inputs yield differences between years would be minimal from these rotations.

Growth rates of forages in different forage options, forage supply and critical periods

Simulated monthly and annual (average of all months) mean daily growth rates of different forages in different rotations are presented in Table 6 (maize rotations), Table 7 (soybean rotations) and Table 8 (sorghum rotations). Growth rates of forages in maize-based rotations were higher compared to forages in other rotations.

There were two common features of grazeable forage supplies in all rotations. Firstly, all rotations (except $\mathrm{Sg} 4$ ) were able to supply grazeable forages to a varied degree for approximately eight months of the year. Secondly, the rest of the four months of the year were critical periods when grazeable forage supplies were not available. These critical periods were approximately two months after sowing of summer forage crops followed by a period of two months after sowing of forage rape in the rotation.

\section{Impact of El-Nino Southern Oscillation events on}

Table 7. Simulated monthly mean daily growth rate $(\mathrm{kg} \mathrm{DM} / \mathrm{ha} / \mathrm{d})$ of forages in soybean and forage rape oversown with ryegrass at different sowing dates $\left(\mathrm{S}^{1}\right)$

\begin{tabular}{|c|c|c|c|c|c|c|c|c|c|c|c|c|}
\hline & \multicolumn{3}{|c|}{$\mathrm{S} 1$} & \multicolumn{3}{|c|}{ S2 } & \multicolumn{3}{|c|}{ S3 } & \multicolumn{3}{|c|}{ S4 } \\
\hline & $\begin{array}{l}\text { Soy- } \\
\text { bean }\end{array}$ & $\begin{array}{c}\text { Forage } \\
\text { rape }\end{array}$ & $\begin{array}{l}\text { Rye } \\
\text { grass }\end{array}$ & $\begin{array}{l}\text { Soy- } \\
\text { bean }\end{array}$ & $\begin{array}{c}\text { Forage } \\
\text { rape }\end{array}$ & $\begin{array}{l}\text { Rye } \\
\text { grass }\end{array}$ & $\begin{array}{l}\text { Soy- } \\
\text { bean }\end{array}$ & $\begin{array}{c}\text { Forage } \\
\text { rape }\end{array}$ & $\begin{array}{l}\text { Rye } \\
\text { grass }\end{array}$ & $\begin{array}{l}\text { Soy- } \\
\text { bean }\end{array}$ & $\begin{array}{l}\text { Forage } \\
\text { rape }\end{array}$ & $\begin{array}{l}\text { Rye } \\
\text { grass }\end{array}$ \\
\hline Jan & 102.3 & 0 & 0 & 70.9 & 0 & 0 & 123.7 & 0 & 0 & 101.4 & 0 & 0 \\
\hline $\mathrm{Feb}$ & 50.6 & 0.7 & 0 & 115.9 & 0 & 0 & 53.8 & 0 & 0 & 57.2 & 0 & 0 \\
\hline Mar & 0 & 18.2 & 0 & 30.5 & 1.7 & 0 & 90.2 & 0 & 0 & 89.5 & 0 & 0 \\
\hline Apr & 0 & 105.2 & 26.1 & 0 & 27.2 & 0 & 0 & 12.5 & 0 & 0 & 7.4 & 0 \\
\hline May & 0 & 26.4 & 28.8 & 0 & 99.3 & 12.7 & 0 & 60.7 & 1.5 & 0 & 49.8 & 0 \\
\hline Jun & 0 & 4.1 & 15.7 & 0 & 20.3 & 17.5 & 0 & 72.4 & 9.5 & 0 & 79.8 & 6.8 \\
\hline Jul & 0 & 33.8 & 34.1 & 0 & 5.4 & 37.9 & 0 & 4.3 & 18.2 & 0 & 12.7 & 18.5 \\
\hline Aug & 0 & 68.3 & 34.2 & 0 & 53.2 & 19.9 & 0 & 12.0 & 42.1 & 0 & 9.7 & 44.8 \\
\hline Sep & 0 & 2.7 & 20.7 & 0 & 52.8 & 50.0 & 0 & 80.9 & 24.5 & 0 & 79.4 & 24.3 \\
\hline Oct & 0.9 & 12.1 & 7.6 & 0 & 3.1 & 22.7 & 0 & 17.6 & 53.0 & 0 & 21.9 & 56.1 \\
\hline Nov & 53.3 & 0 & 0 & 1.4 & 0 & 19.7 & 0 & 0 & 31.6 & 0 & 0 & 45.5 \\
\hline Dec & 102.8 & 0 & 0 & 88.7 & 0 & 0 & 27.4 & 0 & 0 & 2.3 & 0 & 0 \\
\hline Grand average & 25.4 & 22.7 & 14.0 & 25.1 & 22.0 & 14.8 & 24.2 & 21.6 & 14.8 & 20.6 & 21.6 & 16.1 \\
\hline
\end{tabular}

${ }^{1} \mathrm{~S}$ represents sowing dates of forages. Sowing dates and all other agronomic principles can be seen in Table 2 . 
Table 8. Simulated monthly mean daily growth rate $(\mathrm{kg} \mathrm{DM} / \mathrm{ha} / \mathrm{d})$ of forages in sorghum and forage rape intercropped with ryegrass at different sowing dates $\left(\mathrm{Sg}^{1}\right)$

\begin{tabular}{|c|c|c|c|c|c|c|c|c|c|c|c|c|}
\hline & \multicolumn{3}{|c|}{ Sg1 } & \multicolumn{3}{|c|}{$\mathrm{Sg} 2$} & \multicolumn{3}{|c|}{$\mathrm{Sg} 3$} & \multicolumn{3}{|c|}{$\mathrm{Sg} 4$} \\
\hline & $\begin{array}{c}\text { Sor- } \\
\text { ghum }\end{array}$ & $\begin{array}{c}\text { Forage } \\
\text { rape }\end{array}$ & $\begin{array}{l}\text { Rye } \\
\text { grass }\end{array}$ & $\begin{array}{l}\text { Sor- } \\
\text { ghum }\end{array}$ & $\begin{array}{c}\text { Forage } \\
\text { rape }\end{array}$ & $\begin{array}{l}\text { Rye } \\
\text { grass }\end{array}$ & $\begin{array}{c}\text { Sor- } \\
\text { ghum }\end{array}$ & $\begin{array}{c}\text { Forage } \\
\text { rape }\end{array}$ & $\begin{array}{l}\text { Rye } \\
\text { grass }\end{array}$ & $\begin{array}{l}\text { Sor- } \\
\text { ghum }\end{array}$ & $\begin{array}{c}\text { Forage } \\
\text { rape }\end{array}$ & $\begin{array}{l}\text { Rye } \\
\text { grass }\end{array}$ \\
\hline Jan & 86.2 & 0 & 0 & 110.9 & 0 & 0 & 131.7 & 0 & 0 & 43.7 & 0 & 0 \\
\hline Feb & 85.4 & 0 & 0 & 63.6 & 0 & 0 & 43.3 & 0 & 0 & 108.9 & 0 & 0 \\
\hline Mar & 48.2 & 0 & 0 & 57.2 & 0 & 0 & 82.6 & 0 & 0 & 33.2 & 0 & 0 \\
\hline Apr & 47.6 & 0 & 0 & 43.3 & 0 & 0 & 32.1 & 0 & 0 & 34.9 & 0 & 0 \\
\hline May & 0 & 4.7 & 13.1 & 0 & 4.7 & 13.1 & 0 & 4.7 & 13.1 & 0 & 4.7 & 13.1 \\
\hline Jun & 0 & 18.9 & 54.5 & 0 & 19.0 & 54.6 & 0 & 18.4 & 54.5 & 0 & 17.5 & 54.4 \\
\hline Jul & 0 & 8.8 & 8.6 & 0 & 8.9 & 8.8 & 0 & 8.5 & 8.7 & 0 & 7.3 & 8.2 \\
\hline Aug & 0 & 47.1 & 9.1 & 0 & 47.9 & 9.7 & 0 & 47.0 & 9.7 & 0 & 43.8 & 8.2 \\
\hline Sep & 0 & 54.2 & 39.9 & 0 & 56.1 & 40.2 & 0 & 55.6 & 40.4 & 0 & 52.4 & 39.8 \\
\hline Oct & 0 & 17.6 & 20.6 & 0 & 13.2 & 20.4 & 0 & 15.1 & 20.4 & 0 & 18.6 & 21.1 \\
\hline Nov & 3.4 & 0 & 0 & 0.4 & 2.4 & 9.9 & 0 & 13.7 & 20.3 & 0 & 3.3 & 19.9 \\
\hline Dec & 64.7 & 0 & 0 & 41.3 & 0 & 0 & 9.6 & 0 & 0 & 0.7 & 5.3 & 11.0 \\
\hline Average & 27.6 & 12.5 & 12.0 & 26.1 & 12.6 & 12.9 & 24.8 & 13.5 & 13.7 & 17.8 & 12.7 & 14.5 \\
\hline
\end{tabular}

${ }^{1}$ Sg represents sowing dates of forages. Sowing dates and all other agronomic principles can be seen in Table 2 .

\section{simulated yields and irrigation requirements}

There were 56 neutral (normal), 29 La-Nina and 26 ElNino years in 111 years and irrigation and temperature related risks associated with El-Nino years was assessed. Average daily maximum temperature $\left(23.7^{\circ} \mathrm{C}\right)$ and radiation $\left(17.2 \mathrm{MJ} / \mathrm{m}^{2}\right)$ was slightly higher in El-Nino years compared to neutral years (23.2 and 17.0 respectively), but radiation was lower in La-Nina $\left(16.6 \mathrm{MJ} / \mathrm{m}^{2}\right)$ compared to neutral years (Table 9). Under non-limiting irrigation water and $\mathrm{N}$ fertilizer, total DM yield for a particular simulation was similar between neutral and El-Nino or La-Nina years (Table 10). Irrigation water requirements could increase by up to $18 \%, 16 \%$, and $17 \%$ respectively in those rotations in El-Niño years compared to neutral years (Table 10). On the other hand, irrigation requirement could increase by up to $25 \%, 23 \%$, and $32 \%$ in maize, soybean and sorghum based rotations in El-Nino years compared to La-Nina years. However, irrigation requirement could decrease by up to $8 \%, 7 \%$, and $13 \%$ in maize, soybean and sorghum based rotations in La-Nina years compared to neutral years (Table $10)$.

\section{DISCUSSION}

Model comparison (evaluation) with individual forages

\section{used in field studies and in simulations}

The main objective of this APSIM modelling was to explore sustainable forage option technologies tailored to AMS dairy farming systems. However, one of the challenges associated with dealing with modelled yields in practice might occur due to the lack of confidence of the users on whether these data on simulated yields are realistic or not. In order to gain confidence on these simulated yields it is valuable to justify whether such yields can be explained realistically based on agronomic principles and supported (validated) by field data.

In fact, the basis and confidence of organizing simulation forage rotations for AMS herds was based on our experiences from both field experiments and simulation trials on forage rotations at the Camden site. Agronomical evidences came from our research at Camden, which consistently showed that yields in excess of $40 \mathrm{t} \mathrm{DM} / \mathrm{ha}$ can be harvested from a triple-crop CFR (maize for silageforage rape-field peas) under non-limiting $\mathrm{N}$ and water inputs (Garcia et al., 2008; Fariña et al., 2011; Islam and Garcia, 2012). Our simulations using APSIM also revealed that $39 \mathrm{t} \mathrm{DM/ha}$ simulated yield (under non-limiting $\mathrm{N}$ and water) may be achievable from the same triple-crop CFR not only from Camden, but also from Hunter Valley and North Coast sites (Islam and Garcia, 2010). These

Table 9. Mean total rainfall, daily solar radiation, maximum and minimum temperatures during simulated periods from 1900 to 2010 in neutral, La-Nina and El-Nino years

\begin{tabular}{|c|c|c|c|c|c|}
\hline ENSO $^{1}$ events & No. of years & Rainfall (mm) & Radiation $\left(\mathrm{MJ} / \mathrm{m}^{2}\right)$ & Max temp. $\left({ }^{\circ} \mathrm{C}\right)$ & Min temp. $\left({ }^{\circ} \mathrm{C}\right)$ \\
\hline Neutral & 56 & 672.0 & 17.2 & 23.7 & 10.7 \\
\hline La-Nina & 29 & 813.1 & 16.6 & 23.2 & 10.7 \\
\hline El-Nino & 26 & 729.2 & 17.0 & 23.2 & 10.8 \\
\hline Average/total & 111 & 738.1 & 16.9 & 23.4 & 10.7 \\
\hline
\end{tabular}

${ }^{1}$ El-Nino Southern Oscillation. 
Table 10. Impact of El-Niño Southern Oscillation (ENSO) events on simulated yields, irrigation and total water requirement in different forage rotations

\begin{tabular}{|c|c|c|c|c|c|c|c|}
\hline Simula- tions ${ }^{1}$ & Years & $\mathrm{M} / \mathrm{S} / \mathrm{Sg}^{1}$ & Forage rape & Ryegrass & $\begin{array}{c}\text { Total } \\
\text { (t DM/ha) }\end{array}$ & $\begin{array}{l}\text { Irrigation } \\
\quad(\mathrm{mm})\end{array}$ & $\begin{array}{c}\text { Total water } \\
(\mathrm{mm})\end{array}$ \\
\hline \multirow[t]{3}{*}{ M1 } & El-Nino & 12.4 & 10.6 & 5.9 & 28.9 & 639.6 & 1,312 \\
\hline & La- nina & 11.7 & 10.0 & 5.7 & 27.4 & 510.7 & 1,324 \\
\hline & Neutral & 12.2 & 10.0 & 5.8 & 28.0 & 545.5 & 1,275 \\
\hline \multirow[t]{3}{*}{ M2 } & El-Nino & 12.5 & 9.5 & 6.2 & 28.2 & 632.8 & 1,305 \\
\hline & La- nina & 11.7 & 9.5 & 6.1 & 27.3 & 510.7 & 1,324 \\
\hline & Neutral & 12.2 & 9.5 & 6.1 & 27.8 & 552.4 & 1,282 \\
\hline \multirow[t]{3}{*}{ M3 } & El-Nino & 11.0 & 8.6 & 6.3 & 25.9 & 673.8 & 1,346 \\
\hline & La- nina & 10.8 & 8.4 & 6.1 & 25.3 & 554.5 & 1,368 \\
\hline & Neutral & 11.3 & 8.5 & 6.2 & 26.0 & 579.1 & 1,308 \\
\hline \multirow[t]{3}{*}{ M4 } & El-Nino & 10.7 & 8.1 & 6.6 & 25.4 & 671.5 & 1,344 \\
\hline & La- nina & 10.6 & 8.2 & 6.5 & 25.3 & 540.8 & 1,354 \\
\hline & Neutral & 10.6 & 8.2 & 6.5 & 25.3 & 567.2 & 1,296 \\
\hline \multirow[t]{3}{*}{$\mathrm{S} 1$} & El-Nino & 9.6 & 8.3 & 5.2 & 23.1 & 698.5 & 1,371 \\
\hline & La- nina & 9.5 & 8.5 & 5.1 & 23.1 & 567.5 & 1,381 \\
\hline & Neutral & 9.3 & 8.4 & 5.1 & 22.8 & 609.7 & 1,339 \\
\hline \multirow[t]{3}{*}{$\mathrm{S} 2$} & El-Nino & 9.4 & 7.8 & 6.0 & 23.2 & 731.5 & 1,404 \\
\hline & La- nina & 9.4 & 8.2 & 5.3 & 22.9 & 589.3 & 1,402 \\
\hline & Neutral & 9.5 & 8.0 & 5.4 & 22.9 & 633.1 & 1,362 \\
\hline \multirow[t]{3}{*}{$\mathrm{S} 3$} & El-Nino & 9.2 & 8.0 & 5.7 & 22.9 & 722.3 & 1,394 \\
\hline & La- nina & 8.9 & 7.8 & 5.3 & 22.0 & 588.4 & 1,402 \\
\hline & Neutral & 9.0 & 7.9 & 5.6 & 22.5 & 622.6 & 1,352 \\
\hline \multirow[t]{3}{*}{ S4 } & El-Nino & 7.7 & 7.8 & 6.1 & 21.6 & 683.9 & 1,356 \\
\hline & La- nina & 7.3 & 7.8 & 6.0 & 21.1 & 553.0 & 1,366 \\
\hline & Neutral & 7.7 & 8.0 & 6.0 & 21.7 & 595.8 & 1,325 \\
\hline \multirow[t]{3}{*}{ So1 } & El-Nino & 10.8 & 4.5 & 4.4 & 19.7 & 525.4 & 1,197 \\
\hline & La- nina & 9.8 & 4.7 & 4.4 & 18.9 & 400.1 & 1,213 \\
\hline & Neutral & 9.9 & 4.6 & 4.4 & 18.9 & 451.6 & 1,181 \\
\hline \multirow[t]{3}{*}{ So2 } & El-Nino & 9.9 & 4.6 & 4.8 & 19.3 & 493.7 & 1,166 \\
\hline & La- nina & 9.6 & 4.6 & 4.8 & 19.0 & 384.9 & 1,198 \\
\hline & Neutral & 9.6 & 4.7 & 4.8 & 19.1 & 434.6 & 1,164 \\
\hline \multirow[t]{3}{*}{ So3 } & El-Nino & 9.2 & 5.1 & 5.2 & 19.5 & 484.8 & 1,157 \\
\hline & La- nina & 9.0 & 4.9 & 5.1 & 19.0 & 367.5 & 1,181 \\
\hline & Neutral & 9.0 & 4.9 & 5.1 & 19.0 & 422.2 & 1,151 \\
\hline \multirow[t]{3}{*}{ So4 } & El-Nino & 7.0 & 4.8 & 5.5 & 17.3 & 433.3 & 1,105 \\
\hline & La- nina & 6.9 & 4.6 & 5.4 & 16.9 & 326.8 & 1,140 \\
\hline & Neutral & 6.4 & 4.6 & 5.4 & 16.4 & 369.8 & 1,099 \\
\hline
\end{tabular}

${ }^{1} \mathrm{M}, \mathrm{S}$, and Sg represents maize, soybean and sorghum respectively each followed by an intercrop of forage rape-ryegrass rotation. Sowing dates and all other agronomic principles can be seen in Table 2 .

evidences suggest that the dynamic simulation of the APSIM model successfully represented key agronomic, physiological and production system behavior that have occurred in the experimental paddocks or fields. Therefore, it is expected that the simulated forage yields from similar type of forage rotations as those carried out in the present study might be realistic.

In addition, we have also demonstrated that APSIM was able to validate $\left(\mathrm{R}^{2}=0.81\right)$ actual yield of total CFR grown under a range of $\mathrm{N}$ (from 0 to $523 \mathrm{~kg} / \mathrm{ha}$ ) and water (0 to 14
ML water/ha) (Islam and Garcia, 2010). This evidence further suggests that the APSIM model is underpinned by sound scientific-based principles and biologically explainable for forage crop rotations and may be used to explore various other forage rotations as in the present study for the benefit of the livestock industry.

Finally, our measured actual yields of individual forages (used in rotations in this study) from various field trials and then simulation of same forages with the same agronomic principles (e.g. sowing date) and inputs (e.g. $\mathrm{N}$ and water 
rates and timing) used in the field trials revealed that simulated yields were reasonably well correlated to actual forage yields $\left(\mathrm{R}^{2}=0.58\right)$. Therefore, although the simulation rotation scenarios used in this study were not validated using field experiments per se, closely matched simulated and actual yields of individual forages used in the rotations in this study indicate that simulated yields obtained from these forage rotations might be realistic. Nonetheless, one limitation of the validation is that none of the simulations including intercropping of forage rape and ryegrass used in this study was validated using data generated from field studies.

\section{Grazeable forages for automatic milking system herds} and critical periods of supply

The main objective of this study was to identify a suitable forage option that can provide high yield as well as supply grazeable forages for AMS herds throughout the year. The simulated yields indicate that maize-based rotations have the potential to provide between 25.3 and $28.2 \mathrm{t} \mathrm{DM} / \mathrm{ha}$ followed by soybean-based rotations (between 21.5 and 22.9 t DM/ha). Simulated sorghum based rotations supplied lower total forage yields; however, in practice more forage supply may be achieved which will be discussed later. The results presented here indicate that maize-based rotations may have the potential to supply $49 \%$ to $66 \%$ higher yields of grazeable forages for AMS compared to traditional well managed pastures (17 t DM/ha; Garcia et al., 2007b). This in turn may reduce the grazing area at a similar rate required to grow pastures for AMS herds. Therefore, maize-based rotations of this simulation study may have considerable potential to reduce average walking distances of a large AMS herd and consequently may decrease milking interval and increase milk yield. Similarly, there is a good prospect of soybean-based rotations to increase cow-traffic for a large AMS herds as grazeable forage yields from these rotations increased by $27 \%$ to $35 \%$ compared to pastures.

In order to maximise grazing (both grazed yield and grazing days) from these rotations, some principles of grazing may need to follow. For example, grazing of maize can commence when the crop reaches $5 \mathrm{t} \mathrm{DM} /$ ha (or more), which is generally between 45 and 55 days after sowing. The window of opportunity for grazing of maize may last for up to 40 days after which the crop will likely be too mature to graze (crop ends at Zadoks growth stage 8). Similarly, the first grazing of soybean should be expected to commence approximately 55 days after sowing and all areas of the crop should be grazed before initiation of flowering to ensure full potential is harnessed with high re-growth. The subsequent re-growth of soybean should be expected to be grazed after a similar interval. For sorghum, first grazing may be started approximately 50 to 60 days after sowing and then 30 to 40 days after each grazing.

Grazing of forage rape-ryegrass will by default be synchronized as the two forages are intercropped. Some yield may be compromised if grazing must occur at less than ideal maturity for either the forage rape or the ryegrass. Therefore, planning the grazing schedule would be expected to play a significant role in maximization of yield and DM intake from these forages.

Overall, our simulations showed that most rotations used in this study may be able to supply grazeable forages for AMS herds for at least 8 months of the year. The most critical periods when forage supply may not be available were approximately 2 months immediately after sowing of summer forages such as maize, soybean or sorghum and similarly 2 months after sowing of forage rape. Unfortunately these two critical periods have the potential to coincide with periods of reduced pasture supply on the wider farm area particularly for some of the sowing date simulations. One possible solution could be to stagger the sowing date of the forage crops to extend the viable grazing periods thereby increasing the potential to minimise the critical periods in discussion. Another approach could be growing forages that are grazeable during the critical 4 months. Maize or other forages may also be grown and conserved (preferably in more distant paddocks) and may be offered during those critical times. In situations where these approaches are not valid, purchased feed may be necessary to fill the feed gap during these critical periods.

\section{Growth of forages in different forage option rotations}

Our simulated results suggest that the decision on which of the crops should be grown in the rotation in summer to supply forages for AMS herd might influence the total output. Simulation results showed that high forage yield may be achieved from maize-based compared to other rotations. This high potential yield of maize-based rotations was due to a higher yield of both summer and autumnwinter crops compared to soybean and sorghum.

The physiological basis for this high yield of maize is well established. Dry matter production is a function of light interception and the efficiency of use of absorbed radiation (Andrade et al., 1993). The erectophile leaves of maize compared to horizontal leaves of soybean allow a more uniform distribution of the incoming radiation (Awal et al., 2006). This is an advantage for canopy photosynthesis and radiation use efficiency of maize at a high leaf area index. Radiation use efficiency of maize ( $2.77 \mathrm{~g} / \mathrm{MJ})$ is higher than soybean $(1.74 \mathrm{~g} / \mathrm{MJ})$ (Andrade, 1995). As a result, the photosynthetic system of maize was more efficient than soybean, which enables maize to develop more biomass.

Simulated yields of forage rape alone (when over-sown or intercropped with ryegrass) in all forage options were 
lower (4.7 to $10.0 \mathrm{t} \mathrm{DM/ha)} \mathrm{than} \mathrm{reported} \mathrm{yields} \mathrm{(11} \mathrm{to} 14 \mathrm{t}$ DM/ha; Garcia et al., 2008; Neal et al., 2009; Islam and Garcia, 2012). This yield reduction of forage rape when over-sown/intercropped with ryegrass was expected. However, the combined yields of forage rape and ryegrass in many simulated options out-yielded sole forage rape yields reported in the literature. In addition to higher yield of forage rape-ryegrass, ryegrass may provide an opportunity for extended grazing for AMS herds up to spring and early summer. Several authors (Ofori and Stern, 1987; Caviglia et al., 2004) reported that intercropping often out-yielded sole crop due to more efficient use of resources, reduced incidence of weeds, insect, pests and diseases. Echarte et al. (2011) suggested that the more efficient use of resources in intercropping may occur because the component crops use the resources either at different times or acquire resources from different depth and areas of the soil or aerial environment. Caviglia et al. (2004) reported that such efficiency of resources contributes to improve environment by reducing the likelihood of runoff and deep drainage.

The reported decrease in simulated yields of soybean and sorghum observed with the late sowing dates was in line with that of maize suggesting all three chosen summer forage crops underperform with late sowing. Simulated yields of soybean were similar to the actual yield $(8.7 \mathrm{t}$ $\mathrm{DM} / \mathrm{ha}$ ) found in our study at the same location (Islam and Garcia, unpubl. results). However, simulated yields of sorghum were much lower than actual yields previously reported at the same location (17 to $18 \mathrm{t} \mathrm{DM/ha;} \mathrm{Neal} \mathrm{et} \mathrm{al.,}$ 2009). These researchers harvested sorghum 5 to 6 times from spring to autumn. However, in our simulations a maximum of 3 harvests were possible. Therefore, it is likely that higher yields may be achieved from this (sorghum and forage rape-ryegrass) rotation in practice compared to that obtained from the current simulations. In addition to the impact of compromised sowing and grazing dates of the sorghum-based rotations in simulations, another explanation of lower simulated yield might be due to the use of SweetSorghum cultivar instead of traditional sorghum crop in the simulations as the model cannot perform multiple harvests when traditional sorghum was used.

It should be noted that soybean forage options may require some extra precautions in practice during grazing for AMS herds. Firstly, grazing heavily may reduce or even eliminate the chance of re-growth thereby dramatically reducing the overall yields of the soybean forage crop. Secondly, grazing allocation of more than one-fourth of the total dry matter intake of cow's requirement might cause health hazards such as bloat. Similar caution might also be necessary during periods of forage rape grazing (Fulkerson et al., 2008).

\section{Impact of El-Nino Southern Oscillation events on simulated yields and irrigation requirements}

These results indicate that irrigation requirements could increase up to $18 \%$ in El-Nino, but decrease up to $13 \%$ in La-Nino compared to neutral years. This increase in irrigation in El-Nino years resulted in little or no gain in yield in most of the simulated scenarios, which is in agreement with the results of Chauhan (2010). High and low irrigation requirements in El-Nino and La-Nina years, respectively might be attributable to daily average radiation interception and maximum temperature which were higher in El-Nino and lower in La-Nino years compared to neutral years for only a small gain in yield in El-Nino years. This result also agrees with Chauhan (2010), who reported higher solar radiation and maximum temperature in El-Nino years despite similar minimum temperature across ENSO events.

Overall, although the impact of ENSO events were minimal on simulated yields, their impact on irrigation water requirements was significant. As both El-Nino and La-Nina occur on average one in every four year (based on data of 111 years from 1900 to 2010), forecasting tools can potentially be valuable tool in determining water requirement for a particular rotation and year in response to differences in rainfall, so that one can plan optimal area required to supply feed for AMS herds under irrigation for a given amount of irrigation water allocation in El-Nino and La-Nino years.

\section{CONCLUSION}

The results of our study indicate that the APSIM model has the potential to screen grazeable forage options for AMS herds. APSIM simulations also showed that there is a considerable potential to increase grazeable forages (16.9 to $28.2 \mathrm{t} \mathrm{DM} / \mathrm{ha}$ ) for AMS herds compared to current levels of pasture yield (17 t DM/ha) using strategic forage rotations. The results also showed that these simulations may indicate periods of reduced forage availability including critical periods which would require management. One major implication of this study is that APSIM models may assist in devising preferred forage options in order to maximise grazeable forage yield for AMS herds. It may create an opportunity to grow more forage in small areas around the AMS which in turn will minimise walking distance and milking interval and thus increase milk production. Ultimately this should also help to reduce purchased feed and cost of production. Yield variability of the simulated forages in the rotations were minimal between years under non-limiting inputs, but irrigation water requirements were higher in El-Nino years compared to La-Nina and neutral years. Overall, APSIM can be used as a valuable tool to 
assist in devising preferred grazeable forage options in a production system such as for AMS herds. It may also provide decision support by identifying critical periods when alternatives are needed and risk assessment during climatic uncertainty. Further work should be conducted regarding system fitness of the forage crops to the wider farm and herd. This would ensure that a more integral understanding of the full system could be developed including balancing the diet and need for supplementary feeds.

\section{ACKNOWLEDGMENTS}

The authors thank the Dairy Research Foundation for its support of the Dairy Science Group and the investors of the FutureDairy project (Dairy Australia, NSW Department of Primary Industries, The University of Sydney, and DeLaval). The authors also acknowledge Dr K. Pembleton, University of Tasmania for his suggestion in constructing sorghum-based simulations.

\section{REFERENCES}

Andrade, F. H. 1995. Analysis of growth and yield of maize, sunflower and soybean grown at Balcarce, Argentina. Field Crops Res. 41:1-12.

Andrade, F. H., S. A. Uhart, and A. Cirilo. 1993. Temperature affects radiation use efficiency in maize. Field Crops Res. 32:17-25.

Anwar, M. R., G. J. O'Leary, M. A. Rab, P. D. Fisher, and R. D. Armstrong. 2009. Advances in precision agriculture in southeastern Australia. V. Effect of seasonal conditions on wheat and barley yield response to applied nitrogen across management zones. Crop Pasture Sci. 60:901-911.

Awal, M. A., H. Koshi, and T. Ikeda. 2006. Radiation interception and use by maize/peanut intercrop canopy. Agric. For. Meteorol. 139:74-83.

Carberry, P. S., S. G. K. Adiku, R. L. McCown, and B. A. Keating. 1996. Application of the APSIM cropping systems model to intercropping systems. In: Dynamics of Roots and Nitrogen in Cropping Systems of the Semi-Arid Tropics (Eds O. Ito, C. Johansen, J. J. Adu-Gyamfi, K. Katayama, J. V. D. K. Kumar Rao, T. J. Rego) Japan International Research Centre for Agricultural Sciences, Ibaraki, Japan. pp. 637-648.

Caviglia, O. P., V. O. Sadras, and F. H. Andrade. 2004. Intensification of agriculture in the south-eastern Pampas I. Capture and efficiency in the use of water and radiation in double-cropped wheat-soybean. Field Crops Res. 87:117-129.

Chauhan, Y. S. 2010. Potential productivity and water requirements of maize- peanut rotations in Australian semiarid tropical environments-A crop simulation study. Agric. Water Manag. 97:457-464.

Donohue, R. H., K. L. Kerrisk, S. C. Garcia, D. A. Dickeson, and P. C. Thomson. 2010. Evaluation of two training programs aimed to improve early lactation performance of heifers in a pasture- based automated milking system. Anim. Prod. Sci. 50:939-945. Echarte, L., A. Della Maggiora, D. Cerrudo, V. H. Gonzalez, P. Abbate, A. Cerrudo, V. O. Sadras, and P. Calvino. 2011. Yield response to plant density of maize and sunflower intercropped with soybean. Field Crops Res. 121:423-429.

Fariña, S. R., S. C. Garcia, and W. J. Fulkerson. 2011. A complementary forage system whole-farm study: forage utilization and milk production. Anim. Prod. Sci. 51:460-470.

Fulkerson, W. J., A. Horadagoda, J. S. Neal, I. Barchia, and K. S. Nandra. 2008. Nutritive value of forage species grown in the warm temperate climate of Australia for dairy cows: Herbs and grain crops. Livest. Sci. 114:75-83.

Garcia, S. C. and W. J. Fulkerson. 2005. Opportunities for future Australian dairy systems: A review. Aust. J. Exp. Agric. 45:1041-1055.

Garcia, S. C., W. J. Fulkerson, R. Nettle, S. Kenny, and D. Armstrong. 2007a. FutureDairy: A national multidisciplinary project to assist dairy farmers to manage challenges - methods and early findings. Aust. J. Exp. Agric. 47:1025-1031.

Garcia, S. C., J. L. Jacobs, S. L. Woodward, and D. A. Clark. 2007b. Complementary forage rotation: A review. In: Meeting the Challenges for Pasture Based Dairying, Proceedings of the Australian Dairy Science Symposium (Eds. D. F. Chapman, D. A. Clark, K. L. Macmillan, and D. P. Nation). National Dairy Alliance, Melbourne, Australia. pp. 221-239.

Garcia, S. C., W. J. Fulkerson, and S. U. Brookes. 2008. Dry matter production, nutritive value and efficiency of nutrient utilization of a complementary forage rotation compared to a grass pasture system. Grass Forage Sci. 63:284-300.

Isbell, R. F. 2002. Australian Soil Classification. CSIRO Publishing, Collingwood, Victoria, Australia.

Islam, M. R. and S. C. Garcia. 2009. Forage option to increase forage and water productivity in autumn-winter. 14th Dairy Sci. Symp., The University of Sydney, Sydney, Australia. pp. 114116.

Islam, M. R. and S. C. Garcia. 2010. Simulation of a triple-crop complementary forage rotation using APSIM. FutureDairy 2 Milestone Report 12, Modelling Studies Report, July 2010, Milestone report to Dairy Australia, Vic., Australia. pp. 7-19.

Islam, M. R. and S. C. Garcia. 2012. Effects of sowing date and nitrogen fertilizer on forage yield, nitrogen- and water-use efficiency and nutritive value of an annual triple-crop complementary forage rotation. Grass Forage Sci. 67:96-110.

Islam, M. R., S. C. Garcia, and A. Horadagoda. 2012. Effects of residual nitrogen, nitrogen fertilizer, sowing data and harvest time on yield and nutritive value of forage rape. Anim. Feed Sci. Technol. 177:52-64.

Islam, M. R. and S. C. Garcia. 2013. Forage options for dairy cows. 22nd Int. Grassl. Cong., 15-19 September, Sydney, Australia. pp. 1719-1720.

Jago, J. G., K. Bright, P. Copeman, K. Davis, A. K. Jackson, I. Ohnstad, R. Wieliczko, and M. Woolford. 2004. Remote automatic selection for cows for milking in a pasture-based automatic milking system. Proc. NZ Soc. Anim. Prod. 64:241245.

Jago, J. G., K. L. Davis, P. J. Copeman, I. Ohnstad, and M. M. Woolford. 2007. Supplementary feeding at milking and minimum milking interval effects on cow traffic and milking 
performance in a pasture-based automatic milking system. J. Neal, J. S., W. J. Fulkerson, R. Lawrie, and I. M. Barchia. 2009. Dairy Res. 74:492-499.

Jago, J. G. and K. L. Kerrisk. 2011. Training methods for introducing cows to a pasture-based automatic milking system. Appl. Anim. Behav. Sci. 131:79-85.

Keating, B. A., P. S. Carberry, G. L. Hammer, M. E. Probert, M. J. Robertson, D. Holzworth, N. I. Huth, J. N. G. Hargreaves, H. Meinke, Z. Hochman, G. McLean, K. Verburg, V. Snow, J. P. Dimes, M. Silburn, E. Wang, S. Brown, K. L. Bristow, S. Asseng, S. Chapman, R. I. McCown, D. M. Freebairn, and C. J. Smith. 2003. An overview of APSIM, a model designed for farming systems simulation. Eur. J. Agron. 18:267-288.

Kolbach, R., K. L. Kerrisk, S. C. Garcia, and N. Dhand. 2012. Attachment accuracy of a novel prototype robotic rotary and investigation of two management strategies for incomplete milk quarters. Comput. Electron. Agric. 88:120-124.

Lyons, N. A., K. L. Kerrisk, and S. C. Garcia. 2014. Milking frequency management in pasture-based automatic milking system: A review. Livest. Sci. 159:102-116. Difference in yield and persistence among perennial forages used by the dairy industry under optimum and deficit irrigation. Crop Pasture Sci. 60:1071-1087.

Ofori, F. and W. R. Stern. 1987. Cereal-legume intercropping systems. Adv. Agron. 41:41-90.

Pembleton, K. G., R. P. Rawnsley, and D. J. Donaghy. 2011. Yield and water-use efficiency of contrasting lucerne genotypes grown in a cool temperate environment. Crop Pasture Sci. 62:610-623.

Robertson, M. J., W. Sakala, T. Benson, and Z. Shamudzaria. 2005. Simulating response of maize to previous velvet bean (Mucuna pruriens) crop and nitrogen fertilizer in Malawi. Field Crops Res. 91:91-105.

Stockdale, C. R. 1983. Irrigated pasture productivity and its variability in the Shepparton Region of northern Victoria. Aust. J. Exp. Agric. Anim. Husb. 23:131-139.

Zadoks, J. C., T. T. Chang, and C. F. Konzak. 1974. A decimal code for growth stages of cereals. Weed Res. 14:415-421. 